\title{
The settlement of disputes under the WTO. The experience of Latin America and the Caribbean
}

\author{
Gonzalo Biggs
}

$\mathrm{T}$

his article analyses the implications for the Latin America region of the dispute settlement procedure approved in 1994 by the Marrakesh Agreement Establishing the World Trade Organization (wто). These implications are important because the region has become involved in a growing number of commercial disputes as its international trade has increased. The procedure applies to disputes between any of the 148 member countries over matters covered by the Agreement and the 29 multilateral agreements annexed to and forming an integral part of this. The present article highlights the ways in which the procedure differs from the old GATT rules and other international dispute settlement procedures. It describes the agreements that have generated the most disputes (anti-dumping, subsidies and countervailing measures, and safeguards), discusses United States policy in this area and details the disputes in which the Latin American countries have participated, with particular reference to Brazil.

Partner of the law firm of Figueroa and 


\section{I}

\section{Introduction}

Of all international organizations, the most important for Latin America, in our opinion, is the World Trade Organization (што). One author has described it as the most economically influential of all the world's international bodies. ${ }^{1}$

Its importance stems from the macroeconomic reforms and trade liberalization of the 1980s, which turned international trade into the main engine of economic development in the Latin America region, so that volumes all but trebled in a decade. ${ }^{2}$ In 1994 the region's exports and imports totalled US\$ 323 billion, but by 2004 the figure had risen to US $\$ 860$ billion. As might be expected, the rise in the volume of world trade over that period was accompanied by a corresponding increase in international trade disputes or differences. These developments explain why the procedure operated by the wTO Dispute Settlement Body (DSB) is so crucially important for the region's countries. $^{3}$

This article analyses the implications for the Latin America region of this WTO procedure or Dispute Settlement Understanding (referred to hereafter as the Understanding) and covers the following issues: historical background and institutional characteristics; new features and comparison with other procedures; United States policy; most common disputes; the experience of the Latin American and Caribbean countries; the Brazilian experience, and conclusions.

\section{II}

\section{Historical background and institutional characteristics of the wTo}

\section{Background}

The Bretton Woods Conference of 1946 gave birth to the World Bank, the International Monetary Fund (IMF) and the International Trade Organization (гто). The roles of these three institutions were to promote investment for development and to regulate balances of payments and international trade, respectively. The creation of the ITO was negotiated by the United Nations and culminated in the Havana Charter of 1948. Tariff relief, meanwhile, was regulated by the 1947 General Agreement on Tariffs and Trade, better known

\footnotetext{
$\square$ At the recommendation of the Government of Chile, the author has been included in the wTO indicative list of non-governmental experts. He was a panellist in Canada's case against the United States over the provisional countervailing duties applied to softwood imports and in the case brought by Brazil and other countries against the European Communities over sugar subsidies.

${ }^{1}$ See Jackson (1999, p. 101).

${ }^{2}$ In 2004, external trade represented $44 \%$ of the region's GDP (ECLAC, 2004 , p. 8 , and ECLAC, 1994 , p. 39).
}

as GATT, whose application and supervision were assigned to the Iто. The United States Congress, however, did not adopt the ITO, so that GATT came into force without this institutional backing. Its implementation was only ever provisional, moreover, since it never secured the number of ratifications required by its charter. ${ }^{4}$ The gap was filled by a temporary secretariat created by the United Nations, which eventually became permanent, and by article $\mathrm{XXV}$, which established a mechanism enabling the parties (known as the Contracting Parties when acting collectively) to meet and execute the Agreement.

Besides these institutional shortcomings, GATT was born with two major limitations. The first was the

\footnotetext{
${ }^{3}$ The DSB was established by article 2 of the Understanding approved in Marrakesh at the same time as the wTO was established.

${ }^{4}$ Article XXVI of GaTT stipulated that it would come into force upon acceptance by governments named in Annex $\mathrm{H}$ whose territories accounted for $85 \%$ of the total external trade of the territories of those governments. The deadline passed, however, without this target being met. See Petersmann (1997, vol. II, p. 46).
} 
underrepresentation of developing countries, since there were only seven of these among the 23 founder members of GATT. In Latin America, the original signatories of the Agreement were Brazil, Chile and Cuba. $^{5}$

The second limitation was that its work was confined exclusively to regulating customs tariffs on goods trade between industrialized countries, on the basis of the national treatment and most-favourednation principles. Despite these limitations, GATT managed to survive and endure for almost 50 years. In its eight negotiating rounds, furthermore, it was able to adopt decisions, resolutions and protocols that allowed it to develop and expand its sphere of action, its representativeness and, very gradually, its responsibilities towards developing countries.

\section{Disputes under GATT}

Disputes under GATT during the 1948-1994 period of the Agreement were governed by its articles XXII and XXIII which, as will be explained later, remain in force. These articles established the right of Members to bring forward consultations or complaints concerning the application of the Agreement, on the terms set forth therein. They did not establish a procedure for handling disputes, however, but gave the Contracting Parties (and not independent bodies) the authority to resolve them. Nor was there any appeals procedure.

In the initial stages, disputes were submitted directly to the Contracting Parties; subsequently, resolutions were passed on to working groups of up to 20 delegates or representatives of governments (which could include those of the parties in dispute), whose recommendations were submitted to the Contracting Parties for a final decision. In 1952, panels were created to resolve complaints under article XXIII and agreement was reached on the principle that any measure infringing the agreements adopted would be presumed to constitute a case of nullification or impairment of the benefits conferred by GATT rules. Under these new provisions, panel members could no longer be from the parties in dispute, but their recommendations continued to be submitted to the

\footnotetext{
${ }^{5}$ See the Preamble to GatT 1947 in The Legal Texts, Results of the Uruguay Round of Multilateral Trade Negotiations (GATT, 1994). The following citations from the wTO Agreement and its annexed agreements, all approved at Marrakesh, are taken from that publication.
}

Contracting Parties for a final ruling. Subsequent resolutions adopted from 1952 onward made good the lack of a set procedure, culminating in 1989 with the approval of a new set of rules that were more elaborate and objective, and that applied until the end of the Uruguay Round. ${ }^{6}$

However, the fact that final rulings required consensus among all Contracting Parties, including the parties in dispute, mean that disputes were ultimately resolved through diplomatic or political channels. During the period from 1948 to 1994, 196 disputes were resolved but in only one case was authorization given to suspend concessions owing to a Member's non-compliance with its obligations under the Agreement. ${ }^{7}$

\section{Institutional structure of the WTO}

The Uruguay Round was the last GATT negotiating round before the current and still ongoing Doha Round, and it was the first to be held in a developing country. It culminated with the Marrakesh meeting of 15 April 1994 and the approval by the 124 participating countries and the European Communities ${ }^{8}$ of the Marrakesh Agreement Establishing the wTо (referred to hereinafter as the што Agreement) and of 29 annexed multilateral agreements, 28 declarations and ministerial decisions, four plurilateral agreements ${ }^{9}$ and an understanding on financial commitments.

The Uruguay Round negotiations took place at a political and trade ministry level. However, disputes arising from the application of the resulting agreements have been and continue to be settled essentially by legal means, as we explain further on.

Whereas GATT led to a great deal of fragmentation, since the parties did not all ratify the same agreements (for example, two thirds of members did not sign up to the agreements of the 1979 Tokyo Round), the wTO Agreement and annexed agreements approved in Marrakesh constitute an integrated blanket agreement whose texts are equally binding on all Members. ${ }^{10}$ WTO

\footnotetext{
${ }^{6}$ Decision of the Contracting Parties of GatT dated 12 April 1989, approving dispute resolution rules and procedures (wTO, 1995, p. 638). ${ }^{7}$ See Petersmann (1997, vol. II, p. 46).

${ }^{8}$ In wTo usage, the term "European Communities" is used to refer to the European Union, particularly in relation to dispute settlement processes. Accordingly, in this article both terms are used.

${ }^{9}$ The four plurilateral trade agreements are only binding on countries that have ratified them.

${ }^{10}$ Article II (2) and (3) of the wTo Agreement.
} 
rules extend not just to trade in goods and services but also to subsidies, safeguards, anti-dumping measures, rules of origin and other issues covered by the 29 agreements mentioned. The wTO is an organization with an international legal personality (which GATT was not) and is responsible for supervising the application of the main agreement and its annexed agreements, including, of course, the Understanding. ${ }^{11}$

The 148 member countries are always part of the three main wTo bodies - the Ministerial Conference, the General Council and the Dispute Settlement Body (DSB) - and are represented on them. This innovative structure ensures that the decisions taken by these bodies will be multilateral and representative:

i) the Ministerial Conference is an assembly of the ministerial representatives of the Member States. It meets every two years and has the authority to settle any matter covered by the multilateral agreements adopted in Marrakesh;

ii) the General Council is an assembly of the Geneva representatives accredited by the governments of the Member States. It discharges the functions of the Ministerial Conference when the latter is not meeting. It meets as often as it deems necessary and administers and supervises the different Councils established by the Agreement (trade in services, trade in goods and trade-related aspects of intellectual property rights), ${ }^{12}$ and it also acts as the Dispute Settlement Body when required; iii) The Dispute Settlement Body (DSB) is composed of the same representatives as the General Council. It administers the rules and procedures of the Understanding and settles disagreements arising from the application of the multilateral agreements covered. As mentioned above, its functions are performed by the General Council. It meets monthly, and may have its own chairman and approve such rules as it needs to carry out its functions; ${ }^{13}$ and

iv) a Secretariat headed by a Director-General who is appointed by the Ministerial Conference and in turn appoints a staff which he then heads and whose duties and conditions of service he determines. Both the Director-General and the Secretariat staff are international officials and do not accept instructions from any government. ${ }^{14}$

At meetings of the Ministerial Conference and General Council, each member has one vote. The wTO continues the GATT practice of decision-making by consensus, which is deemed to have been reached when no Member present at the meeting where the decision is taken formally opposes it. Thus, an absence or abstention does not block consensus. If consensus is not reached, the decisions of the Ministerial Conference and Council are taken by majority vote, unless otherwise provided. ${ }^{15}$ The exception to this are the rulings of the DSB, which can only be adopted by consensus. ${ }^{16}$

\section{III}

\section{The wTO dispute settlement procedure}

Some novel features of the wTO dispute settlement procedure, which set it apart from any other international procedure of the same kind and account for its efficiency and effectiveness, are the compulsory and exclusive nature of its jurisdiction, its multilateral character, its automaticity, the primacy of law in dispute settlement, the preference for non-contentious solutions, low cost, speed and the procedures for enforcing and implementing resolutions.

${ }^{11}$ See articles VIII and III of the wTo Agreement.

12 See article IV (5) of the wTo Agreement.

\section{Jurisdiction}

The jurisdiction of the wTо is compulsory, exclusive and multilateral.

Any Member country which considers that another Member has violated its obligations under the WTO Agreement or an annexed agreement, or that its benefits have been impaired or nullified, is entitled to initiate the dispute settlement procedure by requesting

\footnotetext{
${ }^{13}$ See article IV (3) of the wTo Agreement.

${ }^{14}$ See article VI of the wTo Agreement.

${ }^{15}$ See article IX (1) of the wTO Agreement.

${ }^{16}$ See article 2 (4) of the Understanding.
} 
consultations. ${ }^{17}$ In certain cases, a Member with a substantial trade interest may (if the consulting Member agrees) be joined in the consultations ${ }^{18}$ and subsequent proceedings.

The Member to which the request for consultations is addressed is obliged to respond and cannot challenge this jurisdiction (as may happen with other bodies), since it automatically accepted it by ratifying the што Agreement and annexed multilateral agreements. This is in contrast to the proceedings of other international tribunals, where challenges to jurisdiction and the like are common and can delay or hold up any settlement of the substance of a dispute for years.

Jurisdiction is also exclusive in the sense that any infringement of WTO agreements can only be judged or remedied in accordance with wTO rules and procedures. ${ }^{19}$ A Member country cannot sue another or seek reparations for such infringements before any jurisdiction or through any proceedings, national or international, other than those established by the wTо system and Understanding.

Furthermore, the procedure is multilateral in a twofold sense. First, because once an agreement has been violated or challenged, the affected party cannot respond with unilateral measures without also committing an infraction. Its only legitimate recourse is to work through the multilateral procedures of the wTO. Second, because each stage in the procedure has to be approved by the DSB, which is composed of representatives from all wто Members. Thus, for example, the start of consultations, the formation of a panel and its ruling, a ruling by the Standing Appellate Body (hereinafter the Appellate Body) or a resolution approving the suspension of concessions or obligations all have to be approved by the DSB. Furthermore, once the procedure has been initiated, any settlement arrived at by mutual agreement between the parties has to be consistent with the wTO Agreement and its annexed agreements, and be notified to the DSB and the relevant Committees. This allows other Members to raise concerns about the consequences this bilateral solution might have for the multilateral agreements concerned. ${ }^{20}$

17 Understanding, article 4 (4)

18 Understanding, article 4 (11).

19 Understanding, article 23 (1) and (2).

${ }^{20}$ Understanding, article 3 (6).

\section{Dispute settlement: primacy of law. Description of the bodies involved}

A radical change from GATT has been the replacement of procedures where political and diplomatic considerations prevailed by one whereby disputes are settled by independent tribunals pursuant to the facts and the relevant law.

The governing law is the set of agreements annexed to the wTO Agreement and forming an integral part of it. GATT 1994 is one of these annexed agreements, and itself includes GATT 1947 and the decisions, procedures and customary practices of its Contracting Parties. ${ }^{21}$

Panels are formed at the request of the complaining country and must be approved by the DSB, unless the latter decides by consensus not to establish a panel..$^{22}$ They are composed of three well-qualified independent governmental and/or non-governmental individuals who cannot be citizens of the parties to the dispute or of third countries involved in the dispute and having a substantial interest in it, unless the parties agree otherwise. ${ }^{23}$ Nominations are made by the Secretariat and may not be opposed except for compelling reasons. ${ }^{24}$ If agreement is not reached, the appointments will be made by the Director-General in consultation with the Chairman of the DSB. ${ }^{25}$

Panels shall have the right to seek information of relevance to the dispute presented from any individual or organization within the jurisdiction of a Member country, on the sole proviso that they first inform the authorities of that country. In turn, Member countries are legally obliged to provide this and a refusal to do so may lead the panel to draw inferences unfavourable to that Member. ${ }^{26}$

The Appellate Body is to be composed of seven persons of recognized authority and demonstrated expertise in law, international trade and the subject matter of the covered agreements generally. They shall be unaffiliated with any government and only three shall serve on any case, in accordance with a predetermined rotation. ${ }^{27}$ They are to be appointed by the DSB for a four-year term, renewable once, and shall

\footnotetext{
${ }^{21}$ Article XVI (1) of the wTo Agreement.

${ }^{22}$ Understanding, article 6.

${ }^{23}$ Understanding, article 8 (1) and (3).

${ }^{24}$ Understanding, article 8 (6).

${ }^{25}$ Understanding, article 8 (7).

${ }^{26}$ Understanding, article 13.

27 Understanding, article 17 (1) and (3).
} 
be broadly representative of the membership of the WTO. ${ }^{28}$ Only the parties may appeal. Third parties which have notified the DSB of a substantial interest may make written submissions and be given a hearing. ${ }^{29}$

The Appellate Body will only consider issues of law or legal interpretations developed by the panel..$^{30}$ It is exclusively for the panel to analyse and assess the facts and evidence. However, it has been determined that consideration of evidence by a panel is a matter of law and thus qualifies for Appellate Body review. Furthermore, it has been argued that GATT, the WTO Agreement and the annexed agreements are an integral part of public international law and thus governed by the general principles of international law. ${ }^{31}$ Accordingly, the Appellate Body regularly invokes the rules of interpretation of the Vienna Convention on the Law of Treaties, particularly article $31 .^{32}$

The resolutions of panels and the Appellate Body do not apply the stare decisis principle of Anglo-Saxon law, whereby courts are obliged to apply the case law established by previous rulings on the same matters. wTo panels and the Appellate Body take their decisions freely on the merit of the facts and the law applicable in each case. In practice, however, even though they are not binding, previous rulings are always analysed and considered thoroughly in every resolution adopted. They are also a principal source of information for countries considering whether to submit a claim to the wTO.

Member countries have to ensure that their laws, regulations and administrative procedures are consistent with the obligations accepted under the WTO Agreement and annexed agreements. ${ }^{33}$ Members are entitled to ask that legislation inconsistent with these (e.g., laws that violate national treatment or the countervailing duties application procedure) be amended or repealed. An example of this is the complaint made by a number of countries, including Brazil, Mexico and Chile, against the United States for

\footnotetext{
28 Understanding, article 17 (2) and (3).

${ }^{29}$ Understanding, article 17 (4).

30 Understanding, article 17 (6).

31 Debra Steger cites the opinion of the Appellate Body in the gasoline case (document WT/DS2/AB/R of 20 May 1996, p. 17), which states that the provisions of the wTO Agreement establishing the organization cannot be read in "clinical isolation" from public international law (Steger, 2005).

${ }^{32}$ Article 31 (1) of the Vienna Convention states: "A treaty shall be interpreted in good faith in accordance with the ordinary meaning to be given to the terms of the treaty in their context and in the light of its object and purpose."

33 Article XVI (4) of the wTo Agreement.
}

the so-called Byrd Amendment of 2000 which altered that country's legislation and authorized the direct payment of countervailing duties to businesses alleging import subsidization or dumping. The ruling, which will be discussed later in this article, accepted the complaint and established that this amendment was contrary to and incompatible with the provisions of the Anti-dumping Agreement (AD Agreement), the Agreement on Subsidies and Countervailing Measures (sCM Agreement) and GATT 1994. ${ }^{34}$

Jurisprudence has distinguished, however, between contrary legislation that is imperative (which can be protested) and legislation that, while contrary, is merely optional or discretionary (which cannot).

\section{Automaticity or the "negative" or "reverse" consensus rule}

By contrast with the resolutions of GATT bodies, which required for their validity the consensus of the Contracting Parties so that just one Member could prevent a panel from being formed or a ruling from being adopted or enforced, at the WTO the reverse consensus rule applies. This means that DSB resolutions take effect automatically unless there is a consensus among Members that they should not be adopted. As is obvious, a Member consensus against the formation of a panel, the approval of a ruling or the suspension of concessions has never occurred. With GATT, on the other hand, it was enough for such resolutions to be rejected by a single Member for consensus to be blocked, which in the end meant that the parties had to negotiate a political solution. This is one of the innovations accounting for the speed and expeditiousness of wто procedures. Thus, when a country requests consultations or the formation of an arbitration panel, DSB resolutions for or against take effect immediately, unless there is a consensus against them. The same is true of DSB resolutions on the rulings of arbitration panels ${ }^{35}$ and the Appellate Body, ${ }^{36}$ or rulings approving the suspension of concessions or other obligations when the respondent party does not comply with the resolutions of the latter. ${ }^{37} \mathrm{In}$ all these cases, the relevant resolutions can only be revoked if there is a Member consensus against their adoption.

\footnotetext{
${ }^{34}$ Documents WT/DS217/AB/R and WT/DS234/AB/R and DSB resolution of 27 January 2003.

${ }^{35}$ Understanding, article 6 (1).

${ }^{36}$ Understanding, article 16 (4).

${ }^{37}$ Understanding, article 22 (6).
} 


\section{Preference for non-contentious solutions}

The first objective of the procedure is to find a positive solution that is mutually acceptable to the parties to the dispute. ${ }^{38}$ Accordingly, contentious proceedings cannot begin right away; instead, the procedure has to start with a request to the DSB for consultations, and the Member complained of is obliged to respond. These consultations are confidential, and only when they fail can the formation of a panel be requested. Without prejudice to this, the procedure allows and encourages the parties, subject to its rules (including notification to the DSB), to settle their bilateral differences at any of the subsequent stages.

\section{Costs}

In comparison with other mechanisms, wTO proceedings have a low cost. The parties do not pay for administration, secretarial costs or arbitration fees. All these costs are met by the Organization out of its general budget. ${ }^{39}$

In international disputes, however, legal costs are the largest item and here too the wTо differs from other bodies. Since October 2001, the Advisory Centre on wто Law has been operating. This Centre is an independent public international body, with its own legal personality, which had 37 member countries as of January 2005 (10 industrialized countries and 27 developing countries). It is based in Geneva and its function is to provide developing countries with legal advice on што issues, particularly dispute settlement, at a reasonable cost. Its current Executive Director was formerly a wTO legal advisor. As of January 2005, Honduras, Nicaragua, Ecuador, Peru, Colombia and Venezuela had received legal advice from the Centre in some of their disputes before the wTO. In some cases this advice was provided directly by the Centre, in others by an outside legal advisor. ${ }^{40}$

\section{Speed}

Once consultations have begun there is a very strict pre-established timetable for the procedure, and extensions can only be granted by the DSB. In practice, wTO proceedings are both faster and more flexible than

\footnotetext{
38 Understanding, article 3 (7).

${ }^{39}$ Understanding, article 8 (11).

40 www.acwl.ch.
}

those of any other international body. The flexibility comes, among other factors, from the non-contentious nature of the consultations with which they begin, most of which end with the parties reaching agreement or the deadline simply expiring without either of the parties requesting the formation of a panel. ${ }^{41}$ It is the exception, then, for disagreements to persist and be settled by a panel. Indeed, in some cases the parties settle their differences by mutual agreement even after a panel has been constituted.

The timetable is 60 days for the consultations ${ }^{42}$ and six months for the panel to issue its ruling (or report when there is no appeal) from the date it is formed. Unless the DSB grants an extension, ${ }^{43}$ in no event may the period between the establishment of the panel and the distribution of the report to Members by the DSB exceed nine months, or 12 months when there is an appeal. ${ }^{44}$ Should there be an appeal, the ruling must be distributed within 60 days from the time the decision to appeal is formally notified. ${ }^{45}$

Once the ruling has been adopted by the panel or the Appellate Body, the affected Member must notify the DSB of its intention to comply with the decisions adopted. If it does not comply with them immediately, it must do so within a reasonable time, which in most cases may not exceed 15 months from the date of the panel or Appellate Body ruling. If the panel or Appellate Body has extended the deadlines for issuing the respective rulings, however, the additional time will be added to the 15 months with the proviso that the total period may not exceed 18 months from the said date, unless the parties agree that there are exceptional circumstances. ${ }^{46}$

\section{Compliance or execution}

If the panel or Appellate Body resolves that the measure complained of is inconsistent with a covered agreement, it will recommend that the Member

\footnotetext{
${ }^{41}$ Of the 317 consultations begun between 1 January 1996 and 22 October 2004, only 129 led to the formation of a panel (see wTo, 2004a, p. 43, paragraph 93).

42 Understanding, article 4 (7).

${ }^{43}$ If the complainant so requests, the work of the panel may be suspended for up to 12 months, in which case the deadlines laid down in the procedure will be extended for the period of this suspension; if work is suspended for more than 12 months, however, the functions of the panel will cease. See Understanding, article 12 (12).

${ }^{44}$ Understanding, article $12(8)$ and (9) and article 20.

45 Understanding, article 17 (5).

46 Understanding, article 21 (3).
} 
concerned bring it into conformity with that agreement, and may suggest how this should be done. ${ }^{47}$

If there is disagreement over the compliance measures or their consistency with a covered agreement, this will be resolved through the same procedure, ideally by the original panel and within 90 days from when the matter is brought before it. ${ }^{48}$ If the Member affected or prejudiced by the report does not comply with the agreed measures within a reasonable time period, that Member will be obliged to negotiate mutually acceptable compensation if the other party so requests. Compensation is voluntary, in that the country may refuse to provide it, in which case concessions may be suspended indefinitely until it comes into compliance. Should compensation be granted, it must be compatible with the relevant agreements. ${ }^{49}$ If this has not happened within 20 days following expiration of the reasonable time period agreed on, any of the parties that has had recourse to the dispute settlement procedure may apply to the DSB for the concessions or other obligations resulting from the covered agreements to be temporarily suspended in respect of the Member concerned. ${ }^{50}$

Suspensions or reprisals will be authorized by the DSB until such time as the measure declared inconsistent with the covered agreement has been removed, or the Member concerned provides a solution to the nullification or impairment of benefits, or a mutually satisfactory solution is reached. ${ }^{51}$ The Member concerned may, however, object to the level of suspension proposed or the procedures followed, in which case the dispute will be submitted for arbitration to the original panel if available or, if not, to an arbitrator appointed by the Director-General. ${ }^{52}$ The level of suspension of concessions or other obligations authorized by the DSB must be equivalent to the level of nullification or impairment of the agreement that has been breached. ${ }^{53}$

In the 10 years that the wто has been operational, there have been only six cases in which compliance with a final Appellate Body ruling has been called into question and the DSB has had to authorize the suspension of concessions or other obligations against

\footnotetext{
47 Understanding, article 19 (1).

48 Understanding, article 21 (5).

49 Understanding, article 22 (1).

50 Understanding, article 22 (2).

51 Understanding, article 22 (8).

52 Understanding, article 22 (6).

${ }^{53}$ Understanding, article 22 (4).
}

the offending member. Three of these six cases involved Latin American countries, something that is discussed below.

\section{Some shortcomings}

One of the shortcomings of the procedure is that it does not make any provision for precautionary or provisional measures to assure the outcome of the dispute for the complainant. Furthermore, the final rulings of panels or the Appellate Body only apply to the future and not from the date on which the infraction complained of occurred.

As for the compensation or suspension of concessions or other obligations that can be imposed on an offending Member to enforce DSB resolutions, these have to be equivalent to the level of nullification or impairment of the breached agreements. ${ }^{54}$ The problem with this requirement of proportionality is that it has only a minimal impact on an industrialized country when the complainant is a developing country. Furthermore, suspending concessions increases the tariffs applicable to the country being penalized, and thus raises import prices for consumers in the importing country. Lastly, perhaps the most serious shortcoming is that the DSB lacks the power to apply coercive measures to enforce its decisions. This limitation contrasts with the regulations governing the International Centre for Settlement of Investment Disputes (ICSID), which give arbitration awards issued in accordance with the ICSID Convention executive force in all Member States of that organization. ${ }^{55}$

\section{Comparison with other mechanisms}

The што has the most efficient dispute settlement procedure of any international body. It is an objective, fast, predictable, low-cost procedure or code of rules which, notwithstanding the limitations referred to, responds effectively to the needs of developing countries. Before it existed, a trade complaint made by a developing country was unlikely to prevail in the courts of an industrialized country or, during the early decades, in GATT bodies. The most fundamental change has been the replacement of a system in which political

\footnotetext{
${ }^{54}$ Understanding, article 22 (4).

${ }^{55}$ See article 54 of the Convention on the Settlement of Investment Disputes between States and Nationals of Other States, which gave rise to ICSID.
} 
considerations predominated by one administered by independent bodies with an obligation to apply a legal statute which recognizes and protects the equality of all Members' rights. What this means, as we shall see, is that any developing country can now bring a successful claim against an industrialized country for non-compliance with its wTо obligations.

Two examples, among many, which would have been impossible under GATT, illustrate the benefits that the wто has brought the Latin American countries.

The first was the complaint by Costa Rica against the United States for its restrictions and safeguards on textile imports. The Panel accepted the complaint and ruled that the United States had failed to show that the Costa Rican exports were causing serious damage or were a real or present threat to its domestic industry, and that its restrictions consequently violated articles 6.2 and 6.4 of the Agreement on Textiles and Clothing. Furthermore, by failing to give preferential treatment to re-exports from Costa Rica, the United States measures violated article $6.6 \mathrm{~d}$ ) of that Agreement. ${ }^{56}$

The second was the complaint by Peru against the European Communities for preventing it from using the designation "sardines" for its exports of that fish, on the grounds that it did not match the European description; this complaint was accepted by the Appellate Body. The ruling stated that the European rules contravened article 2.4 of the Agreement on Technical Barriers to Trade and article XVI (4) of the wTO Agreement, which requires countries to ensure that their laws, regulations and administrative procedures conform to the obligations laid down by annexed agreements like the one mentioned. ${ }^{57}$

The dynamism and broad jurisdiction of the wTO procedure set it apart from the procedures of the International Court of Justice (ICJ) and ICSID, whose Administrative Council is headed by the President of the World Bank, and those operated by GATT until 1995.

The ICJ deals exclusively with disputes between States, and these may formulate reservations or refuse to recognize its jurisdiction as binding. The wTO also administers disputes between States but, unlike the ICJ, does not allow reservations ${ }^{58}$ or any challenge to the jurisdiction of its dispute settlement bodies. The situation of the ICJ is different as 58 of its members, including four of the five permanent members of the United Nations Security Council, have refused to recognize its jurisdiction as binding. ${ }^{59}$ Nor has its performance been particularly impressive. From 1947 to 2004, i.e., in a period of over 57 years, the ICs has handed down only $210^{60}$ rulings and 25 advisory opinions.

As for ICSID, its jurisdiction is limited to disputes between any of its 148 Member States and a national or investor from those States. As of the end of the 2004 financial year, 159 cases had been registered with it since its creation in October 1966 and 86 had been concluded or were pending. ${ }^{61}$

As for GATT, in almost 50 years (from 1948 to 1994) it resolved 196 complaints. ${ }^{62}$ These figures should be compared with the 317 consultations commenced and the 129 panels formed at the wTO in the eight years from 1996 to 22 October 2004, as detailed further on. ${ }^{63}$

\section{IV}

\section{United States policy}

The policy of the United States under both GATT and the wTO has been one of consistent support for free

\footnotetext{
${ }^{56}$ Document WT/DSB/M/29 and DSB resolution of 25 February 1997.

57 Document DS/231/AB/R and DSB resolution of 26 November 2002.

58 Article XVI (5) of the wTo Agreement.

${ }^{59}$ See Petersmann (1997, p. 23).

60 www.icj-cij.org/icjwww/idecisions.htm

${ }^{61} \operatorname{ICSID}(2004$, p. 4).

62 WTO (1995, pp. 771-787).

${ }^{63}$ wTo (2004a, p. 43, paragraph 93).
}

trade and rejection of unfair practices. ${ }^{64}$ This policy has been strongly influenced by the dramatic experience of the 1930s crisis and the mistaken policies which triggered it including, among others, the Smoot-

\footnotetext{
${ }^{64}$ During the Uruguay Round negotiations, the United States agreed to repeal section 301 of its 1974 trade law, which authorized unilateral reprisals against practices by other countries deemed to restrict or discriminate against United States trade. Reprisals were taken against Latin American countries under this law in no fewer than 11 cases. Brazil was one of the countries most affected (see Husted, 1995, p. 261).
} 
Hawley Act, a historic example of trade protectionism of the most primitive kind. ${ }^{65}$

Notwithstanding all this, some powerful pressure groups with great political influence have perpetuated the protection of industries (particularly in agriculture) that could not have survived in a situation of genuinely free trade. ${ }^{66}$ Examples of this include the sugar ${ }^{67}$ and cotton industries. Meanwhile, political circumstances have led governments to adopt measures of protection for specific industries from time to time. A recent example of this was the increase in tariffs on steel imports; this gave rise to a complaint before wTO which we shall discuss further on.

Although support for free trade is still the rule, rulings against the United States by the wTo bodies have given rise, as we shall see, to strong criticism of the organization's procedures and resolutions by different sectors in the country.

Notwithstanding this, in 1997 a United States government report gave unconditional backing to WTO procedures and, specifically, to the consultation mechanism, stating that "the new dispute settlement rules often make it possible for us to enforce што agreements without ever having to reach a panel decision". The report went on to back up its conclusion by citing seven cases that were resolved in this way. ${ }^{68}$

At the same time, until recently, public opinion and political sectors in the United States could not conceive that trade or investment rulings by the country's administrative or legal authorities might be revoked or amended by international tribunals. When this happens, there is a groundswell of indignation against what is perceived as unacceptable intervention in the country's sovereignty. This change has been taking place very gradually, as a result, first, of some resolutions by the arbitration tribunals set up under the bilateral free trade agreement of 1987 with Canada,

\footnotetext{
65 The Smoot-Hawley Act of 1930 raised the trade tariffs of the United States to the highest levels in their history. The result was that foreign trade declined drastically and the depression worsened (see Columbia Electronic Encyclopedia, 2003).

${ }^{66}$ Agricultural support in the countries of the Organisation for Economic Co-operation and Development (OECD) was estimated at US $\$ 350$ billion in 2003, with the United States, the European Union and Japan accounting between them for four fifths of this total (see OECD, 2004).

${ }^{67}$ Protection for the sugar industry would be a stumbling block to approval of a free trade agreement between the United States and the Central American countries (see Barrionuevo and Becker, 2005, p. C1).

68 Office of the United States Trade Representative, Report on Trade Expansion Priorities, cited by Horlick (1998, p. 685).
}

then of some of the rulings by the tribunals established under the North American Free Trade Agreement, of ICSID and, lastly, of the wTO. Some of these experiences have given rise to hostility against international jurisdictions that are perceived as inimical to national sovereignty, and the argument is made that United States laws should only be interpreted by the country's own courts, and not by faceless bureaucrats hidden away in Geneva. Curiously enough, these reactions and this defence of sovereignty parallel former experiences that our region used to have (and still does, but to a lesser degree) with the International Monetary Fund, the conditionality of international financial organizations and the unilateral policies of certain countries.

The current criticisms were articulated by Ralph Nader in a discussion of the wTO Agreement when he argued that "decision-making power now in the hands of citizens and their elected representatives...would be seriously constrained by a bureaucracy and a dispute resolution body located in Geneva, Switzerland that would operate in secret and without the guarantees of due process and citizen participation found in domestic legislative bodies and courts". 69

In response to these reservations, a Senate resolution of March 2003, known as the "Dole proposal", established a five-member Commission which will be responsible for reviewing panel and Appellate Body resolutions that go against the United States and informing the government of its findings. Specifically, the Commission will be required to determine whether these wTO bodies have exceeded their authority or mandate, increased the obligations or diminished the rights of the United States under the Marrakesh Agreement, acted arbitrarily or wilfully or departed from the provisions of article 17.6 of the $\mathrm{AD}$ Agreement (which gives the resolutions of national authorities precedence over those of wTO bodies in antidumping investigations). ${ }^{70}$

A later resolution of the House of Representatives rejected the Appellate Body ruling that safeguards on steel imports were not compatible with the wто agreements. ${ }^{71}$ Since then, however, the United States Government has complied with that ruling.

\footnotetext{
69 Testimony by Ralph Nader before the 104th Congress of the United States in 1994. Cited by Jackson (2003, p. 790).

${ }^{70}$ Senate resolution no. 676 of 20 March 2003.

${ }^{71}$ House of Representatives resolution no. 445 of 18 November 2003.
} 
A more general criticism was voiced by both houses of Congress concerning the interpretation of the Anti-Dumping (AD), Subsidies and Countervailing Measures (SCM) and Safeguards (sG) Agreements. They advised the President to ensure that the different measures specified there were observed or applied in WTO proceedings and argued, among other things, that article 17.6 of the AD Agreement, which establishes that the decisions of national jurisdictions take precedence over those of wTO bodies, applied not only to antidumping investigations but to subsidy and safeguard investigations as well..$^{72}$ One author argues, and we agree, that there is no legal basis for this interpretation. ${ }^{73}$

These apprehensions are contradicted by the General Accounting Office (GAO) report of 30 July 2003. According to this, most of the experts consulted, in both the public and private sectors, considered that the wTо had not exceeded its authority when applying the AD Agreement, that all Members were treated alike and that no new obligations had been imposed and no rights curtailed. However, the rules on causality and unforeseen developments as they related to safeguards were judged to be confused. ${ }^{74}$

There has also been strong and persistent criticism from academic and professional circles. One view which is very widespread, but which is not borne out by the facts, is that panels have "almost universally been deciding against the United States for several years". ${ }^{75}$ The GAO report referred to, however, states that 11 out of 13 complaints by Member countries concerning the compatibility of different United States trade laws with wTo rules were rejected and that out of 21 findings by national authorities in anti-dumping or subsidy investigations, the number of United States findings rejected was equivalent to the number of other countries' findings rejected. ${ }^{76}$

A frequent criticism concerns "judicial activism", or the adoption by wTo bodies of resolutions on matters that are ambiguous, contradictory or unlegislated, or that were not agreed in Marrakesh. According to the critics, panels and the Appellate Body should refrain from settling matters of this kind and should hand them over for solution to the political bodies of the wTO. ${ }^{77}$

These comments have done nothing, however, to shake the support of successive United States governments for the WTO, something that has been manifested in their compliance (albeit after delays and questionable challenges) with rulings against them, as well as in other ways. In addition, the United States has been the largest user of the system. As of May 2005 it had participated as a complainant, respondent or third party in all but one of the disputes settled by the Appellate Body. ${ }^{78}$ This in itself is enough to demonstrate, in our opinion, the support of the United States for the wTo.

A quite balanced United States perspective has been provided by professor John Jackson. He cites two opinions that, in his view, sum up the current debate. The first comes from the Democrat leader Tip O'Neill, who said that "all politics is local". The second is from the economist Peter F. Drucker, for whom "all economics is international". In Jackson's view, reconciling these two perceptions is the great challenge ahead for international trade relations. ${ }^{79}$

\section{$\mathrm{V}$}

\section{The most frequent disputes}

The most frequent disputes involving the Latin American countries, whether as complainants or respondents, have generally concerned the application of the covered agreements on subsidies and countervailing measures (SCM), anti-dumping (AD) and safeguards (SG), and of certain sections of GATT 1994.

\footnotetext{
72 Concurrent resolution of the Senate and the House of Representatives no. 243 of 15 July 2003.

73 Jackson (1999, p. 90).

74 GAO (2003, p. 30).

${ }^{75}$ Ragosta, Joneja and Zeldovich (2003, p. 750).

${ }^{76}$ GAO (2003, p. 12).
}

These agreements are an integral part of the wTO Agreement and are binding on all its Members. ${ }^{80}$ As it happens, criticism of the resolutions of wTo bodies by certain sectors in the United States has mainly been directed, as we shall see, against the way these three covered agreements have been applied and interpreted.

\footnotetext{
77 Ragosta, Joneja and Zeldovich (2003, p. 751).

78 Smith (2004), cited in Shaffer (2005).

79 Jackson (1999, p. 104).

${ }^{80}$ Article II (2) of the wTO Agreement.
} 


\section{Agreement on subsidies and countervailing measures (scm)}

A subsidy exists when there is a financial contribution by a government or any public body within the territory of a Member or there is some form of income or price support conferring a benefit. ${ }^{81}$ Prohibited subsidies are those that are contingent, either solely or as one of several other conditions, upon export performance (in law or fact) or upon the use of domestic over imported goods. ${ }^{82}$ No Member should cause, through the use of any such subsidy, injury to the domestic industry of another Member, or nullification or impairment of benefits accruing directly to it from GATT 1994 (particularly concessions already bound) or serious prejudice to its interests. ${ }^{83}$

Members may only impose countervailing duties after initiating and concluding an investigation accrediting the existence, amount and effects of the alleged subsidy. Investigations must be initiated upon a written application by a branch of domestic industry or, exceptionally, by the authority, when this has sufficient evidence of the existence of a subsidy, the injury caused and the causal relationship between the imports subsidized and the alleged injury. ${ }^{84} \mathrm{By}$ countervailing duty is meant "a special duty levied for the purpose of offsetting any subsidy bestowed directly or indirectly upon the manufacture, production or export of any merchandise, as provided for in paragraph 3 of Article VI of GATT 1994". 85

\section{The Anti-dumping Agreement (AD Agreement)}

The AD Agreement provides that anti-dumping measures are to be applied under the circumstances laid down in article VI of GATT $1994^{86}$ and pursuant to investigations initiated and conducted in accordance with the provisions of that Agreement. ${ }^{87}$ For the purposes of the Agreement, a product is considered to be dumped "i.e. introduced into the commerce of another country at less than its normal value, if the

81 Articles 1.1 and 1.2 of the SCM Agreement.

82 Article 3.1 a) and b) of the SCM Agreement.

83 Article 5 of the SCM Agreement.

84 Articles 10 and 11 of the SCM Agreement.

85 Note 36 to Article 10 of the sCM Agreement. Article VI of GATT 1994 refers to anti-dumping duties and countervailing duties.

86 The circumstances described by article VI of GATT are that a product introduced into the commerce of another country at less than its normal value causes or threatens material injury to an established industry in the territory of a contracting party or materially retards the establishment of a domestic industry.

87 Article 1 of the AD Agreement. export price of the product exported from one country to another is less than the comparable price, in the ordinary course of trade, for the like product when destined for consumption in the exporting country". ${ }^{88}$ Much like the SCM Agreement, the AD Agreement makes the application of countervailing duties conditional on an investigation first being held by a national industry or, exceptionally and when the circumstances justify it, by the authority itself. ${ }^{89}$

Just hours before the conclusion of the Uruguay Round, the United States succeeded in inserting a provision that has been the subject of much controversy. ${ }^{90}$ This is article 17.6, which establishes that panels, in assessing the facts of an AD complaint, must determine whether the local authorities' establishment of the facts was proper and whether their evaluation of those facts was unbiased and objective. If the panel determines that this was the case, the evaluation shall not be overturned even though the panel might have reached a different conclusion. In other words, the assessment of the facts carried out by the local authorities prevails over that carried out by the wTo tribunals. This article adds that the panel must also interpret the relevant provisions of the $\mathrm{AD}$ Agreement in accordance with customary rules of interpretation of public international law. Nonetheless, if it concludes that the provision concerned admits of more than one permissible interpretation, it is to prefer the interpretation that supports the measure adopted by the local authorities. ${ }^{91}$

\section{The Agreement on Safeguards (sG Agreement)}

The SG Agreement governs the application of safeguard measures provided for by article XIX of GATT $1994^{92}$ and establishes that a Member may only apply such measures if that Member has determined, pursuant to the conditions of the Agreement, that a product is

\footnotetext{
${ }^{88}$ Article 2.1 of the AD Agreement.

89 Articles 1 and 5 of the AD Agreement.

90 Petersmann (1997, p. 54, note 98).

91 Article 17.6 ii) of the AD Agreement.

${ }^{92}$ One of the safeguard measures mentioned in article XIX is as follows: "If, as a result of unforeseen developments and of the effect of the obligations incurred by a contracting party under this Agreement, including tariff concessions, any product is being imported into the territory of that contracting party in such increased quantities and under such conditions as to cause or threaten serious injury to domestic producers in that territory of like or directly competitive products, the contracting party shall be free, in respect of such product, and to the extent and for such time as may be necessary to prevent or remedy such injury, to suspend the obligation in whole or in part or to withdraw or modify the concession."
} 
being imported into its territory in such increased quantities, absolutely or relative to domestic production, and under such conditions as to cause or threaten to cause serious injury to the domestic industry that produces like or directly competitive products. The SG Agreement, however, does not mention the "unforeseen developments" to which article XIX of GATT refers as giving rise to excessive imports, and this has led to controversy as to which provision or agreement prevails.
Measures may be adopted only after an investigation by the competent authorities of that Member following a pre-established public procedure. ${ }^{93}$ They shall be applied, moreover, only to the extent necessary to prevent or remedy serious injury and to facilitate adjustment, ${ }^{94}$ and they may not last for more than four years, unless the period is extended. ${ }^{95}$ The Agreement established a Committee on Safeguards under the authority of the Council for Trade in Goods, which monitors and supervises its application. ${ }^{96}$

\section{VI}

\section{The experience of Latin America and the Caribbean ${ }^{97}$}

Between 1 January 1995 and 22 October 2004, 317 consultations were filed with the WTO, leading to the formation of 129 panels for 159 disputes. ${ }^{98}$ These panels issued 90 rulings, of which 59 were appealed, so that in 31 cases the parties accepted the panel findings. ${ }^{99}$ Of the consultations, 188 ended in mutual agreement between the parties, or else their differences were resolved in one way or another and there was no need to form a panel.

Of these consultations, most involved industrialized countries, 204 as complainants and 191 as respondents. Developing countries, meanwhile, initiated 136 consultations and were the respondents in $122 .{ }^{100}$

Most of the consultations concerned antidumping, subsidies and countervailing measures, and safeguards.

Concerning anti-dumping, the countries that have applied the largest number of measures since 1995 have been India (279), the United States (211), the European Union (193) and Argentina (193); the countries against which most measures have been taken are China (272), the European Union and its

\footnotetext{
93 Article 3 of the SG Agreement.

94 Article 5 (1) of the SG Agreement.

95 Article 7 (1) of the SG Agreement.

96 Article 13 (1) of the SG Agreement.

97 The figures in this section differ slightly from those given elsewhere in this document, as the sources are from different periods.

98 WTO (2004a, p. 43, paragraph 93).

99 พTо (2004a, p. 44, paragraph 96).

100 WTO (2004a, p. 44, paragraph 95).
}

member countries (213) and the Republic of Korea (110). ${ }^{101}$

Concerning subsidies and countervailing measures, 168 investigations were notified during the period 1995-2003, the largest numbers being conducted by the United States (69) and the European Union (42). ${ }^{102}$ The countries that have applied the largest number of safeguards, meanwhile, are India (8), the United States (6) and Chile, the Czech Republic and the Philippines, with 5 apiece.

As regards compliance with panel or Appellate Body rulings, the great majority have been complied with within the reasonable time period stipulated by article 21.3 of the Understanding. ${ }^{103}$ The exceptions have been cases where the parties were in disagreement and the party ruled in favour of had to apply for DSB authorization to suspend concessions or other obligations vis-à-vis the offending party. There have been six such cases since 1995 and the following three have involved Latin American countries: 104

- Actions by the United States, Ecuador, Guatemala, Honduras, Mexico and other countries against the banana import restrictions of the European Communities.

- Actions by Canada against Brazil for export financing subsidies in its civil aviation sector.

\footnotetext{
101 wTO (2004a, pp. 34 and 35, paragraph 67).

102 WTO (2004a, p. 35, paragraph 68).

103 wто (2004a, p. 44, paragraph 97) and Understanding, article 21 (3).

104 See the last paragraph of section III, point 7 above.
} 
- Actions by Brazil against Canada for export credits and loan guarantees in its civil aviation sector. ${ }^{105}$

\section{Consultations}

One consequence of the gradual format of the procedure and the preference for non-contentious solutions is that a large proportion of consultations between 1995 and March 2005 ended in agreement between the parties, without the need to form a panel. This outcome has been highlighted by the United States and the European Union as one of the great successes of the procedure.

Brazil and Argentina have been the main Latin American users of the consultation procedure. Brazil has been a complainant in 22 consultations and a respondent in 12, while Argentina has been a complainant in 9 and a respondent in $15 .{ }^{106}$

\section{Disputes settled by the Appellate Body}

Between 20 May 1996 and 19 May 2005, 68 disputes were settled by rulings or final reports from the WTO Appellate Body. ${ }^{107}$

Approximately one third (22) of these 68 rulings were on disputes involving Latin American countries as complainants or respondents, ${ }^{108}$ and in three of the 22 the disputes were wholly between Latin American countries. The other 19, therefore, were between Latin American and non-Latin American countries.

Of these 19 disputes, there were eight in which the Latin American countries brought their actions individually and five in which they did so jointly with other countries.

Latin American countries were respondents in six disputes.

The details of the disputes are given below.

\section{a) Individual actions by Latin American and Caribbean countries}

These were the eight cases that follow, and the rulings went in favour of the complainants in all but two: 109

\footnotetext{
105 wTO (2004a, p. 44, paragraph 97).

106 wTO (2004a, p. 44, paragraph 95).

107 www.wto.org/english/tratop_e/dispu_e/ab_reports_e.html.

108 These 22 rulings include that of 20 April 2005 which settled the dispute between Antigua and Barbuda and the United States over the cross-border supply of gambling and betting services (Appellate Body document WT/DS285/AB/R).

109 The exceptions were the action by Brazil against the European Communities for its restrictions on poultry imports and that of
}

i) Costa Rica versus the United States for its restrictions on textile imports; the ruling went in favour of Costa Rica. ${ }^{110}$

ii) Brazil versus the European Communities for restrictions on poultry imports; the ruling went in favour of the European Communities. ${ }^{11}$

iii) Brazil versus Canada for civil aircraft export subsidies; the ruling went in favour of Brazil. ${ }^{112}$

iv) Peru versus the European Communities for the ban on its use of the term "sardines" in its exports to the region; the ruling went in favour of Peru. ${ }^{113}$

v) Brazil versus the European Communities for application of anti-dumping measures to exports of steel tubes; the ruling went in favour of Brazil. ${ }^{114}$

vi) Argentina versus the United States for application of anti-dumping measures to imports of Argentine steel tubes for the oil industry; the ruling went in favour of Argentina. ${ }^{115}$

vii) Brazil versus the United States for subsidies to the cotton industry; the ruling went in favour of Brazil. ${ }^{116}$

viii) Antigua and Barbuda versus the United States for restrictions on the cross-border supply of gambling and betting services; the ruling went in favour of the United States. ${ }^{17}$

b) Actions by Latin American countries jointly with other countries

There were five of these actions and all the rulings went in favour of the complainants:

i) Brazil and Venezuela versus the United States for its restrictions on gasoline imports. ${ }^{118}$

ii) Ecuador, Guatemala, Honduras, Mexico and the United States against the European Communities for their restrictions on banana imports. ${ }^{119}$

\footnotetext{
Antigua and Barbuda against the United States for its cross-border restrictions on gambling and betting services. The rulings went in favour of the European Communities and the United States, respectively.

110 Document WT/DS24/AB/R of 20 March 1997. This document and others with similar catalogue numbers cited below are Appellate Body reports.

${ }^{111}$ Document WT/DS69/AB/R of 23 July 1998.

112 Document WT/DS70/AB/R of 20 August 1999.

113 Document WT/DS231/AB/R of 23 October 2002.

114 Document WT/DS219/AB/R of 18 August 2003.

115 Document WT/DS268/AB/R of 17 December 2004.

116 Document WT/DS267/AB/R of 21 March 2005.

117 Document WT/DS285/AB/R of 20 April 2005.

118 Document WT/DS2/AB/R of 20 May 1996.

119 Document WT/DS27/AB/R of 25 September 1997.
} 
iii) Brazil, Chile, Mexico, the European Communities and other countries against the United States for the so-called Byrd Amendment. ${ }^{120}$

iv) Brazil, the European Communities and other countries against the United States for safeguards on steel imports. ${ }^{121}$

v) Brazil, Australia and Thailand versus the European Communities for their sugar subsidies. ${ }^{122}$

c) Disputes in which Latin American countries were the respondents

There have been six such disputes and all the rulings but one have gone against the respondents:

i) Philippines versus Brazil for application of countervailing measures against imports of desiccated coconut from the Philippines; the ruling went in favour of Brazil. ${ }^{123}$

ii) The United States versus Argentina for application of duties not included in the schedules of concessions to imports of footwear and apparel; the ruling went in favour of the United States. ${ }^{124}$

iii) Canada versus Brazil for export subsidies to its civil aviation industry; the ruling went in favour of Canada. ${ }^{125}$

iv) European Communities versus Chile for taxes levied by Chile on imports of alcoholic beverages; the ruling went in favour of the Communities. ${ }^{126}$

v) European Communities versus Argentina for safeguards on footwear imports; the ruling went in favour of the Communities. ${ }^{127}$

vi) United States versus Mexico for application of anti-dumping duties to United States fructose syrup imports; the ruling went in favour of the United States. ${ }^{128}$

d) Disputes between Latin American countries There were three such disputes:

i) Mexico versus Guatemala for application of provisional measures to Mexican cement imports; the ruling went in favour of Guatemala. ${ }^{129}$

${ }^{120}$ Document WT/DS217/AB/R of 27 January 2003.

${ }^{121}$ Document WT/DS248/AB/R of 10 December 2003.

122 Document WT/DS265/AB/R of 19 May 2005.

123 Document WT/DS22/AB/R of 20 March 1997.

${ }^{124}$ Document WT/DS56/AB/R of 22 April 1998.

125 Document WT/DS46/AB/R of 20 August 1999.

126 Document WT/DS110/AB/R of 12 January 2000.

127 Document WT/DS121/AB/R of 12 January 2000.

128 Document WT/DS132/AB/RW of 21 November 2001.

129 Document WT/DS60/AB/R of 25 November 1998. ii) Argentina versus Chile for the price band system applied to imports of agricultural products; the ruling went in favour of Argentina. ${ }^{130}$

iii) Honduras versus the Dominican Republic for the latter's application of a stamp tax to the importation and sale of cigarettes; the ruling went in favour of Honduras. ${ }^{131}$

e) The action by Antigua and Barbuda against the United States ${ }^{132}$

This dispute is highlighted here because its subject matter is quite new (application of the General Agreement on Trade in Services) and it is among the latest to have been settled by the Appellate Body. Furthermore, the action was taken by a very small country against the most powerful country on the planet.

Antigua and Barbuda complained about restrictions applied by the United States to the supply of betting services and games of chance over the Internet in general, with particular reference to horse racing. According to the complainant, the schedule of market access concessions approved by the United States ${ }^{133}$ mentioned "other recreational services", and this reference should be understood as including betting services and games of chance. The United States rejected this interpretation and stated that this had never been its intention, since there were three federal laws in force that prohibited games of chance between states and even within certain states. The Panel accepted the complaint, however, because it considered that the schedule had not explicitly forbidden these services, and that the United States had not been able to show that the federal laws invoked fell within the exception of article XIV a) of the General Agreement on Trade in Services, i.e., that they were "necessary to protect public morals or to maintain public order". It also accepted the complainant's objection to the Interstate Horseracing Act, concluding that this discriminated against providers of remote electronic betting services.

The Appellate Body partially overturned the Panel resolution. On the one hand, it accepted the defence of the United States and the legitimacy of the restrictions laid down by the three federal laws and resolved that

\footnotetext{
${ }^{130}$ Document WT/DS207/AB/R of 23 October 2002.

131 Document WT/DS302/AB/R of 19 May 2005.

132 Document WT/DS285/AB/R of 20 April 2005.

133 The schedule of market access concessions was approved by the United States in accordance with article II of GATT, which is one of the agreements annexed to the wTO Agreement.
} 
these were justified as "necessary to protect public morals or to maintain public order". On the other hand, it upheld the Panel resolution and the complaint of Antigua and Barbuda that the Interstate Horseracing Act discriminated against cross-border services supplied over the Internet. Its conclusion was that the United States had not succeeded in demonstrating that the restrictions placed by the Act on foreign providers of these betting services applied alike to domestic providers, and it therefore found that the national treatment rule had been violated, as had article XIV of the General Agreement on Trade in Services itself.

\section{f) Overall outcome}

As the information presented shows, during the period from May 1996 to May 2005 the overall outcome (excluding the three disputes between Latin American countries) is as follows:

- of a total of 19 disputes, the Latin American countries were the complainants (individually or jointly with other countries) in 13 cases, and respondents in 6;

- of their 13 complaints, the Latin American countries prevailed in 11 and lost 2;

- of the 6 complaints against them, the Latin American countries lost all but one;

- of the 19 disputes involving Latin American countries as complainants or respondents, these countries were successful in 12, i.e., two thirds of the total, and unsuccessful in 7;

- of the 12 Latin American successes, 8 were rulings in favour of Brazil. Excluding Brazil, therefore, the other countries had 4 successes;

- of the 7 Latin American defeats, 2 were rulings against Brazil. Excluding Brazil, then, the other countries suffered 5 defeats.

The above figures include the claim by Antigua and Barbuda against the United States as one of the defeats, although in some respects the complainant was successful, as explained above.

\section{VII}

\section{The experience of Brazil}

\section{Summary}

Since 1996, Brazil has used the wTо consistently, and with remarkable success, to resolve its trade disputes. It was the complainant, jointly with Venezuela, in the first case to be brought before the WTO (the gasoline case) and, together with other countries, was also the complainant in one of the latest cases (the proceedings against the European Communities for sugar subsidies).

Brazil has participated in 10 disputes before the WTO. It has been the complainant in 8 cases and lost only one, while of the 2 in which it has been the respondent, it lost one. In total, 8 successes and 2 defeats.

Brazil's two defeats were: in its action against the European Communities for the latter's restrictions on poultry imports, and in the action against it by Canada for subsidies to its civil aviation industry, which are mentioned below. table 1 .

The 10 disputes involving Brazil are shown in

\section{Description of the disputes involving Brazil}

There follows a brief description of the main actions involving Brazil, as we believe that they are instructive and important. a) Brazil and Venezuela versus the United States for its restrictions on gasoline imports

On 12 April 1995, Brazil complained, jointly with Venezuela, against the regulations on foreign gasoline imports approved by the United States. Amendments to the latter's Clean Air Act of 1990 established that only clean or "reformulated" gasoline could be sold in the most polluted metropolitan areas. The complainants argued that the methodology used by this law was discriminatory and subjected imported gasoline to less favourable treatment than domestic gasoline. The Appellate Body upheld the complaint and resolved that these regulations represented "unjustifiable discrimination" and "a disguised restriction on international trade" prohibited by article XX of GATT 1994, and it ordered the United States to modify them and bring them into line with the relevant rules of GATT 1994. ${ }^{134}$

b) Philippines versus Brazil for countervailing measures applied to imports of desiccated coconut Brazil applied provisional and permanent countervailing measures to imports of desiccated

\footnotetext{
${ }^{134}$ Document WT/DS2/R and DSB resolution of 20 May 1996.
} 
TABLE 1

Appellate Body resolutions involving Brazil as a party

\begin{tabular}{|c|c|c|c|}
\hline Complainant & Issue & Respondent & Outcome \\
\hline Brazil and Venezuela & Restrictions on gasoline imports & United States & $\begin{array}{l}\text { Favourable to Brazil and } \\
\text { Venezuela }\end{array}$ \\
\hline Philippines & $\begin{array}{l}\text { Countervailing measures on desiccated coconut } \\
\text { imports }\end{array}$ & Brazil & Favourable to Brazil \\
\hline Brazil & Restrictions on poultry imports & European Communities & $\begin{array}{l}\text { Favourable to the } \\
\text { Communities }\end{array}$ \\
\hline Brazil & Subsidies for aircraft exports & Canada & Favourable to Brazil \\
\hline Canada & Subsidies for aircraft exports & Brazil & Favourable to Canada \\
\hline $\begin{array}{l}\text { Brazil, Chile, Mexico } \\
\text { and other countries }\end{array}$ & $\begin{array}{l}\text { Byrd amendment (anti-dumping and subsidies } \\
\text { and countervailing measures agreements) }\end{array}$ & United States & $\begin{array}{l}\text { Favourable to Brazil and } \\
\text { others }\end{array}$ \\
\hline Brazil & Anti-dumping duties on imports of steel tubes & European Communities & Favourable to Brazil \\
\hline $\begin{array}{l}\text { Brazil, European } \\
\text { Communities and others }\end{array}$ & Subsidies for steel imports & United States & $\begin{array}{l}\text { Favourable to Brazil and } \\
\text { others }\end{array}$ \\
\hline Brazil & Subsidies for the cotton industry & United States & Favourable to Brazil \\
\hline Brazil and others & Subsidies for the sugar industry & United States & Favourable to Brazil \\
\hline
\end{tabular}

Fuente: Prepared by the author.

coconut from the Philippines. However, the Appellate Body declined to consider the Philippines complaint for formal reasons, as it considered that the country's legal justification was erroneous and was not specified in the relevant mandate. ${ }^{135}$

c) Brazil versus the European Communities for restrictions on Brazilian poultry imports

The final resolution of this Brazilian action before the WTO went against Brazil.

Brazil argued that the European Communities had not complied fully with their obligation to apply the tariff rate quota for poultry products established in a bilateral agreement between the two countries, and had therefore violated article XXVIII of GATT, which regulates amendments to schedules of concessions. Brazil also argued that there had been infringements of article XIII of GATT, concerning non-discriminatory application of quantitative restrictions, article X of GATT on transparency, various provisions of the Agreement on Import Licensing Procedures between the two parties, the national treatment rules of GATT and the

${ }^{135}$ Document WT/DS22/AB/R and DSB resolution of 20 march 1997. special safeguard provisions of article 5 of the Agreement on Agriculture.

The Panel, among other considerations, found that Brazil had not demonstrated that the European Communities had failed to properly administer the tariff rate quota for poultry imports. The Panel findings were appealed but the Appellate Body upheld its conclusions with some alterations. The two resolutions were adopted by the DSB on 23 July $1998 .{ }^{136}$

\section{d) Brazil versus Canada for civil aircraft export subsidies $^{137}$}

Brazil and Canada had a long-running dispute over the two countries' subsidies for their respective civil aviation industries, since resolved by mutual agreement between the parties.

There were two main disputes and two subsidiary ones, the latter arising from the failure to reach agreement on compliance with the respective rulings of the Appellate Body.

\footnotetext{
136 Document WT/DS69/AB/R of 23 July 1998.

137 Document WT/DS70/AB/R of 20 August 1999.
} 
The complaint brought by Brazil, which was settled in the country's favour, will now be described.

Brazil complained against the subsidies provided by Canada and some of its provinces to the country's aircraft industry, arguing that they were prohibited by articles 3.1 a) and 3.2 of the SCM Agreement. On 14 April 1999, the Panel found that two of the measures complained of were "contingent in fact upon export performance" and thus prohibited by these articles.

The Appellate Body accepted the Brazilian complaint and ordered the removal of the measures complained of. Agreement was not reached on compliance with the ruling, however, so that Brazil asked for authorization to suspend concessions and other obligations by means of countermeasures under articles 22.2 of the Understanding, 4.10 of the SCM Agreement and VI (6)(a) of GATT for the equivalent of US $\$ 3.36$ billion. This request was rejected by Canada and the matter was referred to arbitration under article 22.6 of the Understanding. The arbitration finding approved the suspension of concessions and the adoption of "appropriate countermeasures" but found that, under article 4.10 of the SCM Agreement, the appropriate sum was US\$247,797,000, and Brazil was authorized to implement suspensions for this amount. Notwithstanding this, the arbitrator ruled that, in accordance with article 22.8 of the Understanding, the suspension of concessions and other obligations was to be temporary and apply only until the prohibited measure had been removed. The arbitrator also added that he knew the parties were holding consultations to arrive at a mutually satisfactory solution and that, given the circumstances of the case and the wider context, this seemed to be the most appropriate solution. ${ }^{138}$

\section{e) Canada versus Brazil for civil aircraft export subsidies ${ }^{139}$}

This complaint by Canada was against Brazil's subsidized financing of the Export Financing Programme (Programa de Financiamento às Exportações-PROEX), which promoted civil aircraft exports, and the panel for this was established on 23 July 1998 .

The Appellate Body accepted the complaint that interest paid under PROEX constituted a subsidy within the meaning of article 1 of the SCM Agreement. It found that Brazil had not complied with its obligation under

\footnotetext{
138 See articles VIII and III of the wTo Agreement.

139 Document WT/DS46/AB/R of 20 August 1999.
}

article 27.4 of that Agreement to "not increase the level of its export subsidies". Furthermore, being subsidies "contingent upon export performance", they were subject to the prohibitions of article 3.1 a) of the same Agreement. It went on to uphold the panel conclusion that Brazil had not demonstrated that subsidies to PROEX had not been used to "secure a material advantage in the field of export credit terms". ${ }^{140}$ In the light of these considerations it was ruled that Brazil should withdraw aircraft export subsidies under PROEX, and this was upheld by the DSB on 20 August 1999 .

Since no agreement was reached on compliance by Brazil with the ruling, Canada requested the formation of a panel under article 21.5 of the Understanding, and this was established on 9 December 1999. In its report, the Panel concluded that Brazil had not brought PROEX into conformity with the SCM Agreement. Brazil appealed and also requested arbitration ${ }^{141}$ to determine the justification for the countermeasures requested by Canada. The Appellate Body confirmed the Panel finding that Brazil had not brought PROEX into conformity with the SCM Agreement, and this was upheld by the DSB on 4 August 2000.

The arbitrators ruled that Canada would be justified in applying countermeasures of up to 344 million Canadian dollars a year for six years and suspending concessions for that amount. This was upheld by the DSB on 12 December 2000. On that same date, Brazil notified the DSB of the changes made to PROEX and argued that it was now in conformity with the SCM Agreement. Canada disagreed, however, and made a second application for a panel under article 21.5 of the Understanding. This time the Panel concluded that the revisions made by Brazil to PROEX III were not inconsistent with the SCM Agreement, and this finding was upheld by the DSB on 23 August 2001 .

f) Brazil, Chile, Mexico, the European Communities and other countries versus the United States over the Byrd Amendment ${ }^{142}$

The United States legislation of 2000 known as the Byrd Amendment amended a 1930 Tariff Act and allowed import duties collected by the Treasury under anti-dumping and countervailing duties legislation to be transferred to the businesses that had reported breaches of this legislation.

\footnotetext{
${ }^{140}$ See Annex I of the sCM Agreement.

${ }^{141}$ For the concept of arbitration, see section III, point 7 above.

142 Brazil was one of a number of complainants. This reference is to the Brazilian claim only.
} 
The Appellate Body found that this Amendment was a specific anti-dumping or anti-subsidy measure that was not permitted by and was contrary to the $\mathrm{AD}$ and SCM Agreements. It found that the United States had violated those Agreements and article XVI (4) of the што Agreement which obliges Member countries to ensure that their laws, regulations and administrative procedures are consistent with their obligations under multilateral covered agreements. By committing these infractions, it found, the United States had nullified or impaired the benefits conferred upon the complainants by those agreements.

The parties were unable to agree on the measures to be adopted by the United States to comply with the ruling, and Brazil requested authorization to suspend tariff concessions and obligations under GATT 1994; this was submitted to arbitration. The resolution adopted established that Brazil could suspend concessions by levying additional import duties on a definitive schedule of products originating in the United States. This schedule would cover, each year, a total trade value no greater than the amount yielded by a particular equation. This would take into account the amount of reimbursements under the Byrd Amendment during the last year for which data were available on the antidumping or countervailing duties paid by Brazil that year, multiplied by a coefficient calculated to ensure that the level of suspension would be equivalent to that of the nullification or impairment of the benefits conferred upon Brazil by the breached agreements. ${ }^{143}$ The United States reported that on 3 March 2005 a bill repealing the Byrd Amendment had been submitted to the House of Representatives. ${ }^{144}$

\section{g) Brazil versus the European Communities over anti-dumping duties on malleable cast iron tube or pipe fittings from Brazil \\ Brazil made a complaint against the European} Communities for infringing the AD Agreement by applying anti-dumping duties to these imports. Chile reserved its third-party rights and formulated observations on the ruling.

The Appellate Body ruled that the Communities had violated articles 6.2 and 6.4 of the AD Agreement by not providing Brazilian exporters, during the investigation of the anti-dumping claims, with the information they had available on the factors listed in

${ }^{143}$ Document WT/DS217/AB/R of 31 August 2004.

144 Information on the DSB of 21 March 2005, in wTO (2005). article 3.4 of that Agreement affecting the domestic industry concerned. Since these economic factors and indicators influenced the state of the domestic industry affected by the dumping, Brazilian exporters were unable to mount a proper defence during that investigation. The Appellate Body ruled in favour of Brazil because it considered that the timely provision of this information by the European Communities was an essential part of the process and that the failure to provide it could not be remedied after the event.

h) Brazil, the European Communities and other countries versus the United States over safeguards on steel imports

The European Communities, Brazil and other countries made a complaint against the safeguards applied to steel imports by the United States on the grounds that they had violated articles XIX (1) (a) of GATT 1994 and 3.1 of the SG Agreement. The claim was based on the alleged failure by the United States to provide an adequate and detailed explanation of the "unforeseen developments" leading to such increased quantities of imports in such amounts as to cause serious injury to the relevant domestic producers.

The Appellate Body accepted the complaints and added that the application of safeguards to certain steel products was inconsistent with the requirements of articles 2.1 and 3.1 of the SG Agreement, since the United States did not explain the grounds for its determination concerning the rise in imports. The Body also judged it to be inconsistent with articles 2.1 and 4.2 of the SG Agreement, in that the United States did not comply with the requirement of "parallelism" between the products for which the safeguards were established and the products to which the measures were applied. ${ }^{145}$ The Appellate Body recommended, and the DSB agreed, that the measures objected to should be brought into conformity with the provisions of the SG Agreement, and on 4 December 2003 the White House announced that these measures were to be lifted ${ }^{146}$

i) Brazil versus the United States over cotton industry subsidies

The complaint by Brazil against the United States over subsidies to the latter's cotton industry was

\footnotetext{
${ }^{145}$ Document WT/DS251/AB/R and DSB resolution of 10 December 2003.

146 www.whitehouse.gov.newsrelease.
} 
accepted by the Appellate Body and approved by the DSB on 21 March 2005. The finding was that the payments and support provided by the United States to that industry, put at over US\$ 3 billion a year, violated the Agreement on Agriculture, the SCM Agreement and GATT 1994. They constituted a form of "support to a specific commodity" prohibited by the Agreement on Agriculture, and those provided during 1999, 2000, 2001 and 2002 exceeded the amounts provided in 1992 and were subject to the actions of articles 5 and 6 of the SCM Agreement and XVI (1) of GATT 1994. Furthermore, they undervalued domestic prices and were thus harmful to imported products, infringing article 6 (2) (ii), and were prohibited subsidies under the terms of articles 3.1 (b) and 3.2 of the SCM Agreement, respectively. The credits and guarantees provided were judged to be subsidies contingent upon export performance, and thus also illegal under the SCM Agreement. The conclusion was that the measures referred to were not compatible with the Agreement on Agriculture and the sсM Agreement and that they should be brought into conformity with the provisions of these agreements.

j) Brazil, Australia and Thailand versus the European Communities over their subsidies to the sugar industry (2005)

One peculiarity of this dispute was that besides the parties directly involved, a total of 22 countries reserved third-party rights, including China, Canada, the United States, India and sugar-producing countries in Africa, the Caribbean and the Pacific. These latter

\section{VIII}

\section{Conclusions}

While governments should always give priority to diplomacy for resolving their trade conflicts with other countries, ${ }^{148}$ the virtue of the wTO procedure is that its

\footnotetext{
${ }_{147}$ Article 3.3, article 8 and article 9.1 a) and c) or, alternatively, article 10.1 of the Agreement on Agriculture and article I, part 1.1, points a) 1) i) and a) 1) iv) and points a) 2) and b) of the SCM Agreement.

${ }^{148}$ A good example of the successful use of diplomacy to settle or prevent disputes were the negotiations undertaken by Chile to prevent the European Communities from applying safeguards to salmon imports.
}

groups of countries, known as "ACP countries", receive financial support from the European Communities.

The complainants argued that the subsidies granted to the sugar industry by the European Communities were above the limits specified in the respective schedules of concessions, and that this violated the Agreement on Agriculture and the SCM Agreement. In particular, the complainants argued that the European Communities guaranteed a high price for sugar included in the respective production quotas, but that sugar in excess of these quotas, known as "C sugar", could not be sold internally but had to be exported. The high prices paid to producers and processors enabled these to finance the production and export of $\mathrm{C}$ sugar at prices lower than the cost of production. Furthermore, it was argued that the Communities provided export subsidies to approximately 1.6 million tons, with a value equivalent to that of the imports received from the ACP countries. Because the values and volumes of these exports exceeded the limits committed to and agreed, the subsidies of the European Communities breached the relevant provisions of the Agreement on Agriculture and the SCM Agreement. ${ }^{147}$

The Panel resolution accepted the complainants' arguments, and it was upheld by the Appellate Body. The infractions by the European Communities were ruled to have nullified or impaired the benefits that the Agreement on Agriculture conferred upon the complainants and it was recommended that the Communities amend their rules on sugar and bring them into compliance with the provisions of that Agreement. consultations often yield quite similar solutions. The information analysed shows that when consultations fail and disputes are referred for a panel ruling, the results have usually gone in favour of the Latin American countries. This must be put down to the predictability of the procedure and the fact that it is administered by independent tribunals that objectively apply and interpret rules agreed at a multilateral level.

Given that the disputes concerned are exclusively between States, but concern and affect private-sector interests, it is vital for governments to coordinate closely with domestic exporters and importers. This 
coordination should be ongoing rather than arising as an ad hoc response to a particular dispute. Its aim should be preventive, so that problems can be anticipated and the necessary measures or courses of action taken. It is usually foreign affairs or trade ministries, or both, that represent the interests of States before the WTO in these matters. Nonetheless, the complex technical nature of these issues means that governments need specialist professional back-up, particularly in the legal area, if they are to deal with them properly. One option that many countries, particularly weaker ones, should consider before initiating or responding to a complaint is to seek advice from the Advisory Centre on wTo Law in Geneva, referred to earlier, as its charges are far lower than any international law firm's.

The pattern of jurisprudence over the last 10 years means that the results of disputes can be predicted, at least in some matters, and countries need to study it carefully before presenting a complaint. Sometimes, however, domestic political factors trigger hasty reactions whose sole object is to placate local public opinion or respond to pressure, some of it ill-advised, from the private-sector industry affected. Not only do these reactions generally prove unfruitful, but their ultimate effect is invariably to undermine the credibility of governments, and they should always be resisted.
There are two options that Latin American governments ought to consider.

One is to participate fairly frequently as interested third parties in disputes that affect their interests, even if only indirectly. This kind of participation does not involve large costs and it enables governments to familiarize themselves with the procedures and workings of the system, and thereby acquire the experience they need to cope successfully with future disputes before the wто.

The other option is for governments to consider joining forces with other countries, particularly OECD ones, in large-scale disputes. When they have done so, the results have usually been favourable. Examples of this include the following complaints: Ecuador, the United States and other countries versus the European Communities over restrictions on banana imports; Brazil, the European Communities and other countries versus the United States over tariffs levied on steel imports; and Brazil, Chile, Mexico and the European Communities over the Byrd Amendment. The results of all these cases went in favour of the complainants, and it is possible that this would not have happened had the Latin American countries acted alone.

(Original: Spanish)
Barfield, C. (2004): Testimony on the WTO before the Small Business Committee of the United States House of Representatives, 7 July.

Barrionuevo, A. and E. Becker (2005): Fewer friends in high places for this lobby, The New York Times, New York, 2 June.

Columbia Electronic Encyclopedia (2003): The Smoot-Hawley Law, sixth edition.

ECLAC (Economic Commission for Latin America and the Caribbean) (1994): Preliminary Overview of the Economies of Latin America and the Caribbean, 1994, LC/G.1846, Santiago, Chile.

(2004): Preliminary Overview of the Economies of Latin America and the Caribbean, 2004, LC/G.2265-P, Santiago, Chile, December. United Nations publication, Sales No. E.04.11.G.147.

GAO (General Accounting Office) (2000): World Trade Organization. U.S. Experience in Dispute Settlement System: the First Five Years, Washington, D.C., 20 June.

(2003): World Trade Organization. Standard of Review and Impact of Trade Remedy Rulings, Washington, D.C., 30 July.

GATT (General Agreement on Tariffs and Trade) (1994): The Results of the Uruguay Round of Multilateral Trade Negotiations: The Legal Texts, Geneva, GATT secretariat, December.

Horlick, G.N. (1998): The consultation phase of WTO dispute resolution: a private practitioner's view, The International Lawyer, vol. 32, No. 3, Chicago, Illinois, American Bar Association.
Husted, S.L. (1995): Western Hemisphere free trade and United States trade laws: the role of section 301, Trade Liberalization in the Western Hemisphere, Washington, D.C., Inter-American Development Bank/Economic Commission for Latin America and the Caribbean (ECLAC).

ICSID (International Centre for Settlement of Investment Disputes) (2004): ICSID Annual Report, 2004, Washington, D.C.

Jackson, J.H. (1999): The World Trade Organization. Constitution and Jurisprudence, London, The Royal Institute of International Affairs.

Jackson, J.H. (2003): Sovereignty-Modern: A New Approach to an Outdated Concept, The American Journal of International Law, vol. 97, No. 4, at http://www.asil.org/ajil/jackson.pdf.

Jung, Y. and E. Jooyeon Kang (2004): Towards an ideal safeguards regime, The International Lawyer, vol. 38, No. 4, Chicago, Illinois, American Bar Association.

OECD (Organisation for Economic Co-operation and Development) (2004): Agricultural Policies, 2004, Paris, at www.oecd.org.

Petersmann, E. (1997): International trade law and the GATT/WTO dispute settlement system 1948-1996: an introduction, Studies in Transnational Economic Law, vol. 11, The Hague, Kluwer Law International.

Ragosta, J., N. Joneja and M. Zeldovich (2003): WTO dispute settlement: the system is flawed and must be fixed, The International Lawyer, vol. 37, No. 3, Chicago, Illinois, American Bar Association. 
Shaffer, G. (2005): Weaknesses and Proposed Improvements to the WTO Dispute Settlement System: An Economic and Marketoriented View, wTO Appellate Body Regional Meeting (São Paulo, 16 and 17 May 2005).

Smith, J. (2004): Inequality in international trade? Developing countries and institutional change in WTO dispute settlement, Review of International Political Economy, vol. 11, No. 3, London, Routledge.

Steger, D. (2005): The WTO in Public International Law: Jurisdiction, Interpretation and Accommodation, wTO Appellate Body Regional Meeting (São Paulo, 16 and 17 May 2005).

Tegel, S. (2004): The wTO cotton case, Berkeley Review of Latin American Studies, Berkeley, University of California.

United States House of Representatives (2003): Resolution 445 expressing the disapproval of the House of Representatives with respect to the report issued on November 10, 2003, by the World Trade Organization (WTO) Appellate Body which concluded that United States safeguard measures applied to the importation of certain steel products were in violation of certain
WTO agreements, calling for reforms in the WTO dispute settlement system, and for other purposes, 18 November 2003. United States Senate (2003): Resolution no. 676 to establish a WTO Dispute Settlement Review Commission, and for other purposes, Washington, D.C., 20 March 2003.

United States Senate/United States House of Representatives (2003): Concurrent resolution no. 243 Expressing the sense of the Congress regarding dispute settlement proceedings in the World Trade Organization, Washington, D.C., 15 July.

WTO (World Trade Organization) (1995): Analytical Index. Guide to GATT Law and Practice, Geneva.

(2004a): Overview of Developments in the International Trading Environment: Annual Report by the Director-General, 2004, Geneva.

(2004b): A Handbook on the WTO Dispute Settlement System, Cambridge, Cambridge University Press.

(2005): News 2005, Geneva, 21 March.

, Archive list of panel and Appellate Body reports, at www. wto.org. 